\title{
Exploration of Plant Species Used by Bapedi Ethnic Group for Ethnoveterinary Purposes: A Case Study of Ga-Mphahlele Region in the Limpopo Province, South Africa
}

\author{
Sebua Silas Semenya ${ }^{1}$, Sekgothe Mokgoatšana ${ }^{2}$ and Alfred Maroyi ${ }^{3, *}$
}

${ }^{1}$ Technology Transfer Office, Research Administration and Development Department, University of Limpopo, Private Bag X1106, Sovenga 0727, South Africa; ${ }^{2}$ School of Social Sciences, Department of Cultural and Political Studies, University of Limpopo, Private Bag X1106, Sovenga 0727, South Africa; ${ }^{3}$ Medicinal Plants and Economic Development (MPED) Research Centre, Department of Botany, University of Fort Hare, Private Bag X1314, Alice 5700, South Africa

\begin{abstract}
The use of plant resources by the Bapedi people in the Limpopo province in South Africa is regarded as part of their tradition and culture. This study was aimed at documenting ethnoveterinary uses of plants in Ga-Mphahlele region in the Limpopo province, South Africa. Information was gathered through semi-structured questionnaires supplemented by field observations from 30 randomly selected Pedi speaking people in Ga-Mphahlele region of the Limpopo province. A total of 52 plant species from 32 plant families were used for 18 ethnoveterinary purposes. The majority of the species $(21.2 \%)$ were used as fodder, followed by ethnoveterinary medicinal applications against wounds $(19.2 \%)$, diarrhoea (17.3\%), ticks (13.5\%) and worms (11.5\%) in domestic animals such as cattle, chickens, dogs, donkeys, doves, goats and sheep. The species with frequency of citation (RFC) higher than 0.70 included Citrullus lanatus (fodder), Vachellia karroo (ethnoveterinary medicine and fodder), Sclerocarya birrea subsp. caffra (fodder), Aloe ferox (ethnoveterinary medicine), Drimia sanguinea (ethnoveterinary medicine), Sarcostemma viminale subsp. viminale (ethnoveterinary medicine) and Sorghum bicolor (fodder). The traditional knowledge about forage and ethnoveterinary medicines demonstrated by the Bapedi people enable extension officers and policy makers to appreciate how local communities perceive and utilize plant resources around them.
\end{abstract}

Keywords: Bapedi, ethnoveterinary, Limpopo province, medicinal plants, traditional knowledge.

\section{INTRODUCTION}

The role of ethnoveterinary plants in livestock development and health is common in Africa where there is limited access to modern veterinary care, and this is emphasised by studies conducted in different countries such as Uganda [1], Tanzania [2,3], Ethiopia [4], Zimbabwe [5], Ethiopia [6] and Ivory Coast [7]. Livestock is an integral part of many households inhabiting rural areas and will continue to be intimately linked to their everyday lives. Cost, inaccessibility and other problems like side effects of modern animal health care system have encouraged the local people to developed their own system of keeping animals healthy through ethnoveterinary medicines [8]. Phondani et al. [8] argued that ethnoveterinary practices are often cheap, safe and based on locally available resources and therefore, can serve as an important alternative to modern animal health care systems. In many developing countries, local communities interface ethnoveterinary medicine and modern veterinary health care systems to treat their

\footnotetext{
*Address correspondence to this author at the Medicinal Plants and Economic Development (MPED) Research Centre, Department of Botany, University of Fort Hare, Private Bag X1314, Alice 5700, South Africa; Tel: +27719600326; Fax: +27866177642; E-mail: amaroyi@ufh.ac.za
}

ISSN: 2223-3806 / E-ISSN: 1927-5951/19 livestock, the later is often unavailable due to either staffing problems in agriculture extension services or because synthetic drugs are expensive and ethnoveterinary medicine therefore plays an important role in the animal health care system in developing countries and this approach is perceived as simple, cost-effective, environment friendly, contextually appropriate and culture-based [9]. Other researchers like Suroowan et al. [10], Aziz et al. [11] and Patil [12] argue that ethnoveterinary medicine is often the only available alternative to rural, peri-urban and marginalized populations of the developing world particularly in South Asian and African countries. Previous research showed that livestock play a diverse role in the livelihoods of people in the peri-urban, rural and marginalized areas, as an important source of fertiliser, income, employment, transport and clothing among other uses [1-7]. In South Africa, similar studies were conducted among diverse ethnic groups such as Batswana [13], Xhosa [14-16], Vhavenda [17-18] and Zulu [19]. Despite the availability of these studies, there is no survey that focused on documenting ethnoveterinary practices among the Bapedi people of the Limpopo province in South Africa. Bapedi people are one the prominent cultural group in the country, particularly in the Limpopo province, South Africa. According to Lodge [20], the Bapedi people is the (C) 2019 SET Publisher 
largest ethnic group in the Limpopo province, accounting $57 \%$ of the total population in the Limpopo province. For most parts of the Bapedi communities, the rich indigenous knowledge on plant species used for veterinary purposes is not adequately documented. Therefore, the present study was aimed at documenting plant species used by the Bapedi people for ethnoveterinary purposes in Ga-Mphahlele region in the Limpopo province of South Africa. Such documentation of ethnoveterinary practices and medicinal plant resources is important due to changing socio-economic and cultural values of the traditional communities as the indigenous practices of livestock rearing and ethnoveterinary practices are changing throughout the world $[8,9,21]$.

\section{MATERIALS AND METHODS}

\section{Study Site}

This study was undertaken in Ga-Mphahlele region of the Lepelle-Nkumpi Municipality, located in Limpopo province, South Africa (Figure 1). The majority (87.2\%) of indigenous people in the studied area belong to the Bapedi ethnic group [22]. The regional climate is subtropical with very hot, humid summers and a cooler, dry and sunny winter season lasting from June to September [23]. Mean annual rainfall ranges from 300 to $500 \mathrm{~mm}$ [24]. Daily temperatures vary from mid $-20^{\circ} \mathrm{C}$ to mid- $30^{\circ} \mathrm{C}$, with an average range of between $16^{\circ} \mathrm{C}$ and $28^{\circ} \mathrm{C}$ in summer and $5^{\circ} \mathrm{C}$ to $21^{\circ} \mathrm{C}$ in winter [24]. According to the vegetation classification of Mucina and Rutherford [25], the study areas have a semi-arid savanna, characterized by a mixture of trees, shrubs and grasses. Dominant plants species include Boscia albitrunca (Burch.) Gilg \& Gilg-Ben., Combretum hereroense Schinz, Croton gratissimus Burch., Dombeya autumnalis I.Verd, Hippobromus pauciflorus (L.f.) Radlk., Kirkia wilmsii Engl., Cheilanthes dolomiticola (Schelpe) Schelpe \& N.C. anthony, Sansevieria hyacinthoides (L.) Druce and Plectranthus neochilus Schltr. [25].

The local leaders were provided with the details of the study and its objectives. A total of 30 participants were randomly selected and were requested to sign a consent form. Research by Crouch and McKenzie [26], Guest et al. [27] and Latham [28] showed that saturation often occurs when 12 participants in homogeneous groups and for a heterogenous sample, the number of participants should be at least 12. Data was collected using semi-structured questionnaires during face-to-face interviews which were conducted in Sepedi, the local language. These participants included 20 males and 10 females, who were aged between 31 to 80 years. The questionnaires were designed to capture information on plant species used for veterinary purposes, used part/s and methods of preparation. Voucher specimens were collected during field walks with the participants. Preliminary

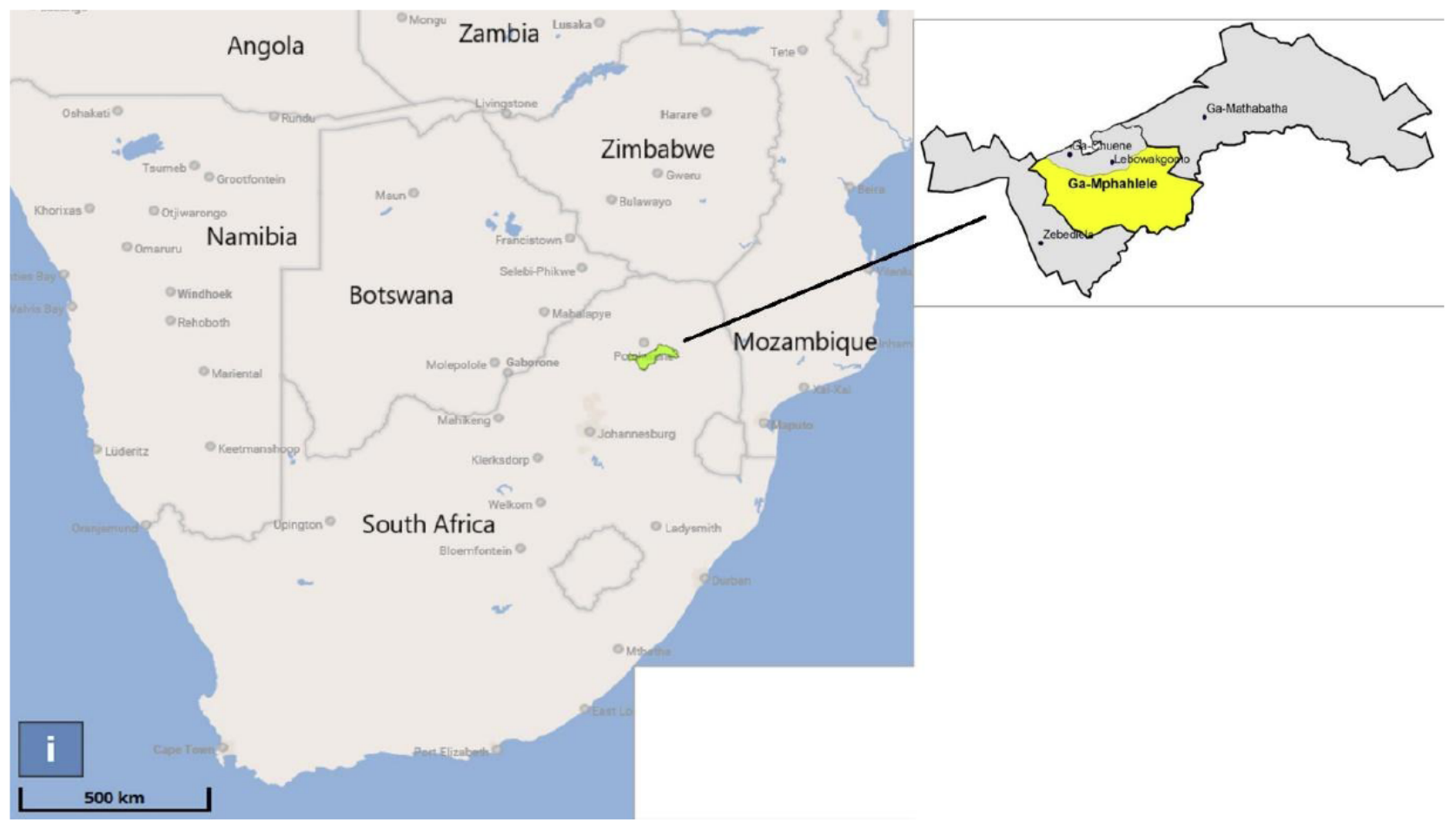

Figure 1: Map of southern Africa showing Ga-Mphahlele region, the study area in the Limpopo province, South Africa. 
Table 1: Plants Used for Veterinary Purposes in Ga-Mphahlele Area of the Limpopo Province, South Africa. Species Marked with an Asterisk (*) are Exotic to South Africa

\begin{tabular}{|c|c|c|c|c|c|}
\hline Species and family name & Parts used & Habit & Preparation methods & Utilisation & RFC \\
\hline $\begin{array}{l}\text { Citrullus lanatus (Thunb.) } \\
\text { Matsum. \& Nakai, Cucurbitaceae }\end{array}$ & Fruits & Herb & Chopped and given to donkeys & Food for donkeys & 0.93 \\
\hline \multirow[t]{3}{*}{$\begin{array}{c}\text { Vachellia karroo (Hayne) Banfi \& } \\
\text { Glasso, Fabaceae }\end{array}$} & \multirow[t]{2}{*}{ Roots } & \multirow[t]{3}{*}{ Tree } & $\begin{array}{l}\text { Pounded and mixed with salt and } \\
\text { mixture given to sheep }\end{array}$ & Diarrhoea in sheep & 0.33 \\
\hline & & & Boiled and extract given to dogs & $\begin{array}{l}\text { Increase aggression and speed } \\
\text { in dogs }\end{array}$ & 0.33 \\
\hline & Leaves & & $\begin{array}{c}\text { Dry or fresh leaves given to } \\
\text { livestock }\end{array}$ & $\begin{array}{l}\text { Fodder for cattle, doves, } \\
\text { donkeys, sheep and goats }\end{array}$ & 0.90 \\
\hline $\begin{array}{l}\text { Sclerocarya birrea (A.Rich.) } \\
\text { Hochst. subsp. caffra (Sond.) } \\
\text { Kokwaro, Anacardiaceae }\end{array}$ & $\begin{array}{l}\text { Fruits and } \\
\text { leaves }\end{array}$ & Tree & Fruits and leaves & $\begin{array}{l}\text { Fodder for cattle, donkeys, } \\
\text { sheep, goats and pigs }\end{array}$ & 0.77 \\
\hline Aloe ferox Mill., Asphodelaceae & Leaves & Shrub & Juice applied topically & Ticks in cattle & 0.73 \\
\hline $\begin{array}{l}\text { Drimia sanguinea (Schinz) } \\
\text { Jessop, Hyacinthaceae }\end{array}$ & Bulb & Herb & $\begin{array}{l}\text { Crushed and macerated in warm } \\
\text { water and applied topically }\end{array}$ & $\begin{array}{c}\text { Wounds in cattle, } \\
\text { donkeys, sheep, goats } \\
\text { and pigs }\end{array}$ & 0.73 \\
\hline $\begin{array}{l}\text { Sarcostemma viminale (L.) R.Br. } \\
\text { subsp. viminale, Apocynaceae }\end{array}$ & Bark & Shrub & Boiled and extract given to livestock & Diarrhoea in pigs & 0.73 \\
\hline $\begin{array}{c}\text { Sorghum bicolor (L.) Moench, } \\
\text { Poaceae }\end{array}$ & Whole plant & Shrub & Dry or fresh parts given to livestock & $\begin{array}{l}\text { Fodder for cattle, doves, } \\
\text { donkeys, sheep, goats } \\
\text { and pigs }\end{array}$ & 0.73 \\
\hline \multirow{2}{*}{$\begin{array}{l}\text { Ficus thonningii Blume, } \\
\text { Moraceae }\end{array}$} & \multirow[t]{2}{*}{ Leaves } & \multirow[t]{2}{*}{ Tree } & Dry or fresh leaves given to pigs & Fodder for pigs & 0.33 \\
\hline & & & Pounded and applied topically & $\begin{array}{l}\text { Wound dresser in cattle, } \\
\text { donkeys, sheep and goats }\end{array}$ & 0.63 \\
\hline $\begin{array}{l}\text { Dichrostachys cinerea (L.) Wight } \\
\text { \& Arn., Fabaceae }\end{array}$ & Fruits & Tree & Dry or fresh fruits & Fodder for sheep & 0.60 \\
\hline \multirow[t]{2}{*}{$\begin{array}{c}\text { Lippia javanica (Burm.f.) Spreng, } \\
\text { Verbenaceae }\end{array}$} & \multirow[t]{2}{*}{ Leaves } & \multirow[t]{2}{*}{ Shrub } & \multirow[t]{2}{*}{$\begin{array}{l}\text { Crushed and macerated in warm } \\
\text { water and applied topically }\end{array}$} & $\begin{array}{l}\text { Ticks in cattle, donkeys, } \\
\text { sheep and goats }\end{array}$ & 0.60 \\
\hline & & & & $\begin{array}{c}\text { Flies in chickens and } \\
\text { doves }\end{array}$ & 0.23 \\
\hline \multirow[t]{2}{*}{ *Zea mays L., Poaceae } & Seeds & \multirow[t]{2}{*}{ Shrub } & Dry or fresh seeds given to livestock & $\begin{array}{l}\text { Food for doves and } \\
\text { chickens }\end{array}$ & 0.37 \\
\hline & Whole plant & & Dry or fresh parts given to livestock & $\begin{array}{l}\text { Fodder for cattle, donkeys, } \\
\text { sheep, goats and pigs }\end{array}$ & 0.60 \\
\hline $\begin{array}{l}\text { Adansonia digitata L., } \\
\text { Bombacaceae }\end{array}$ & Bark & Tree & Pounded and given to livestock & $\begin{array}{l}\text { Fodder for doves, } \\
\text { chickens, sheep and goats }\end{array}$ & 0.57 \\
\hline \multirow[t]{3}{*}{$\begin{array}{l}\text { *Nicotiana tabacum L., } \\
\text { Solanaceae }\end{array}$} & \multirow[t]{3}{*}{ Leaves } & \multirow[t]{3}{*}{ Shrub } & $\begin{array}{l}\text { Boiled and cold extract given to } \\
\text { livestock }\end{array}$ & $\begin{array}{l}\text { Constipation in cattle, } \\
\text { donkeys, sheep and goats }\end{array}$ & 0.57 \\
\hline & & & $\begin{array}{l}\text { Boiled and cold extract applied } \\
\text { topically }\end{array}$ & $\begin{array}{l}\text { Eye infections in cattle, } \\
\text { donkeys, sheep, goats } \\
\text { and pigs }\end{array}$ & 0.33 \\
\hline & & & $\begin{array}{l}\text { Pounded and mixed with leaves of } \\
\text { Dodonaea viscosa var. angustifolia }\end{array}$ & Wounds in cattle and pigs & 0.33 \\
\hline \multirow[t]{2}{*}{$\begin{array}{l}\text { Tribulus terrestris L., } \\
\text { Zygophyllaceae }\end{array}$} & \multirow[t]{2}{*}{ Leaves } & \multirow[t]{2}{*}{ Herb } & \multirow[t]{2}{*}{ Boiled and extract given to livestock } & $\begin{array}{l}\text { Facilitate birth in goats, } \\
\text { sheep and cows }\end{array}$ & 0.57 \\
\hline & & & & $\begin{array}{l}\text { Diarrhoea in goats, sheep } \\
\text { and cattle }\end{array}$ & 0.30 \\
\hline $\begin{array}{l}\text { Aloe marlothii A.Berger, } \\
\text { Asphodelaceae }\end{array}$ & Leaves & Tree & $\begin{array}{l}\text { Juice squeezed and mixed with } \\
\text { drinking water }\end{array}$ & $\begin{array}{l}\text { Newcastle disease in } \\
\text { chickens }\end{array}$ & 0.50 \\
\hline $\begin{array}{l}\text { *Lantana camara L., } \\
\text { Verbenaceae }\end{array}$ & Leaves & Shrub & $\begin{array}{l}\text { Crushed and macerated in warm } \\
\text { water and applied topically }\end{array}$ & $\begin{array}{l}\text { Ticks in cattle, donkeys, } \\
\text { sheep and goats }\end{array}$ & 0.40 \\
\hline
\end{tabular}


(Table 1). Continued.

\begin{tabular}{|c|c|c|c|c|c|}
\hline Species and family name & Parts used & Habit & Preparation methods & Utilisation & RFC \\
\hline $\begin{array}{l}\text { Peltophorum africanum Sond., } \\
\text { Fabaceae }\end{array}$ & Bark & Tree & $\begin{array}{l}\text { Pounded and mixed with drinking } \\
\text { water }\end{array}$ & Internal parasites in cattle & 0.37 \\
\hline $\begin{array}{c}\text { Withania somnifera (L.) Dunal, } \\
\text { Solanaceae }\end{array}$ & Roots & Shrub & $\begin{array}{l}\text { Pounded and mixed with drinking } \\
\text { water }\end{array}$ & $\begin{array}{l}\text { Cold and cough in } \\
\text { chickens and doves }\end{array}$ & 0.37 \\
\hline $\begin{array}{l}\text { Myrothamnus flabellifolius } \\
\text { Welw., Myrothamnaceae }\end{array}$ & Leaves & Herb & $\begin{array}{l}\text { Pounded and mixed with drinking } \\
\text { water }\end{array}$ & $\begin{array}{l}\text { Enhance appetite in cattle } \\
\text { and sheep }\end{array}$ & 0.33 \\
\hline $\begin{array}{c}\text { Senegalia senegal (L.) Britton, } \\
\text { Fabaceae }\end{array}$ & $\begin{array}{l}\text { Fruits and } \\
\text { leaves }\end{array}$ & Tree & Fruits and leaves given to livestock & $\begin{array}{l}\text { Fodder for sheep and } \\
\text { goats }\end{array}$ & 0.27 \\
\hline $\begin{array}{c}\text { Cassia abbreviata Oliv. subsp. } \\
\text { beareana (Holmes) Brenan, } \\
\text { Fabaceae }\end{array}$ & Bark & Tree & $\begin{array}{l}\text { Pounded and mixed with water and } \\
\text { applied topically }\end{array}$ & $\begin{array}{l}\text { Dermatophilosis in cattle, } \\
\text { donkeys, sheep, goats } \\
\text { and pigs }\end{array}$ & 0.23 \\
\hline $\begin{array}{l}\text { Olea europaea L. subsp. } \\
\text { africana (Mill.) P.S.Green, } \\
\text { Oleaceae }\end{array}$ & Leaves & Tree & $\begin{array}{l}\text { Pounded and mixed with drinking } \\
\text { water }\end{array}$ & $\begin{array}{l}\text { Constipation in cattle, } \\
\text { donkeys, sheep and goats }\end{array}$ & 0.23 \\
\hline $\begin{array}{l}\text { Capparis tomentosa Lam., } \\
\text { Capparaceae }\end{array}$ & Roots & Tree & Boiled and extract given to livestock & $\begin{array}{l}\text { Diarrhoea in cattle and } \\
\text { sheep }\end{array}$ & 0.13 \\
\hline $\begin{array}{l}\text { *Citrus limon (L.) Burm., } \\
\text { Rutaceae }\end{array}$ & Fruits & Tree & $\begin{array}{l}\text { Squeezed and mixed with drinking } \\
\text { water }\end{array}$ & Worms in chickens & 0.13 \\
\hline $\begin{array}{l}\text { Ziziphus mucronata Wild., } \\
\text { Rhamnaceae }\end{array}$ & Roots & Tree & $\begin{array}{l}\text { Pounded and mixed with salt and } \\
\text { applied topically }\end{array}$ & $\begin{array}{l}\text { Wound dresser in cattle, } \\
\text { donkeys, sheep and goats }\end{array}$ & 0.13 \\
\hline *Allium cepa L., Amaryllidaceae & Bulbs & Herb & $\begin{array}{l}\text { Crushed, macerated in water and } \\
\text { mixed with drinking water }\end{array}$ & $\begin{array}{l}\text { Constipation in cattle, } \\
\text { chickens, goats and sheep }\end{array}$ & 0.10 \\
\hline $\begin{array}{l}\text { *Aloe vera (L.) Burm, } \\
\text { Asphodelaceae }\end{array}$ & Leaves & Shrub & $\begin{array}{l}\text { Juice squeezed and mixed with salt } \\
\text { and applied topically }\end{array}$ & $\begin{array}{l}\text { Wounds in cattle, sheep } \\
\text { and goats }\end{array}$ & 0.10 \\
\hline $\begin{array}{c}\text { Dombeya rotundifolia Hochst., } \\
\text { Malvaceae }\end{array}$ & Leaves & Tree & Boiled and extract given to livestock & $\begin{array}{l}\text { Diarrhoea in cattle, sheep } \\
\text { and goats }\end{array}$ & 0.10 \\
\hline *Urtica urens L., Urticaceae & Leaves & Herb & $\begin{array}{l}\text { Crushed and macerated in warm } \\
\text { water and applied topically }\end{array}$ & Wounds in donkeys & 0.10 \\
\hline Ximenia caffra Sond., Olacaceae & Leaves & Tree & $\begin{array}{l}\text { Pounded and mixed with water and } \\
\text { applied topically }\end{array}$ & $\begin{array}{l}\text { Dermatophilosis in cattle, } \\
\text { donkeys, sheep, goats } \\
\text { and pigs }\end{array}$ & 0.10 \\
\hline $\begin{array}{c}\text { Zanthoxylum capense (Thunb.) } \\
\text { Harv., Rutaceae }\end{array}$ & Bark & Tree & $\begin{array}{l}\text { Pounded and mixed with drinking } \\
\text { water }\end{array}$ & Worms in goats and sheep & 0.10 \\
\hline $\begin{array}{c}\text { *Agave americana L., } \\
\text { Agavaceae }\end{array}$ & Leaves & Tree & $\begin{array}{l}\text { Crushed and macerated in warm } \\
\text { water }\end{array}$ & $\begin{array}{l}\text { Wounds dresser in cows, } \\
\text { goats and sheep }\end{array}$ & 0.33 \\
\hline $\begin{array}{l}\text { Allium sativum L., } \\
\text { Amaryllidaceae }\end{array}$ & Bulbs & Herb & $\begin{array}{l}\text { Chopped and added to drinking } \\
\text { water }\end{array}$ & $\begin{array}{l}\text { Worms in chickens and } \\
\text { sheep }\end{array}$ & 0.33 \\
\hline $\begin{array}{c}\text { Asparagus falcatus L., } \\
\text { Asparagaceae }\end{array}$ & Roots & Shrub & Boiled and extract given to livestock & $\begin{array}{l}\text { Constipation in cattle, } \\
\text { chickens and doves }\end{array}$ & 0.33 \\
\hline \multirow[t]{2}{*}{$\begin{array}{l}\text { Bulbine latifolia (L.f.) Roem. et } \\
\text { Schult., Asphodelaceae }\end{array}$} & \multirow[t]{2}{*}{ Leaves } & \multirow[t]{2}{*}{ Shrub } & $\begin{array}{l}\text { Pounded and mixed with water and } \\
\text { applied topically }\end{array}$ & Ticks in cattle & 0.33 \\
\hline & & & $\begin{array}{c}\text { Pounded and mixed with water and } \\
\text { given to livestock }\end{array}$ & Worms in cattle & 0.33 \\
\hline *Carica papaya L., Caricaceae & Leaves & Tree & 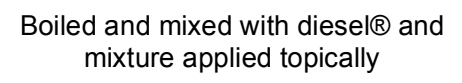 & Ticks in cattle & 0.33 \\
\hline $\begin{array}{l}\text { Carissa edulis Vahl, } \\
\text { Apocynaceae }\end{array}$ & Leaves & Tree & $\begin{array}{l}\text { Pounded and mixed with petrolß or } \\
\text { diesel } ® \text { and mixture sprayed on } \\
\text { livestock }\end{array}$ & Heart-water in cattle & 0.33 \\
\hline $\begin{array}{l}\text { Elephantorrhiza elephantina } \\
\text { (Burch.) Skeels, Fabaceae }\end{array}$ & Roots & Shrub & $\begin{array}{l}\text { Pounded and mixed with petrolß or } \\
\text { water and mixture sprayed }\end{array}$ & $\begin{array}{c}\text { Ticks in donkeys and } \\
\text { cattle }\end{array}$ & 0.33 \\
\hline $\begin{array}{l}\text { Combretum molle R.Br. ex } \\
\text { G.Don, Combretaceae }\end{array}$ & Leaves & Tree & $\begin{array}{l}\text { Pounded and mixed with drinking } \\
\text { water }\end{array}$ & Fertility in sheep & 0.33 \\
\hline
\end{tabular}


(Table 1). Continued.

\begin{tabular}{|c|c|c|c|c|c|}
\hline Species and family name & Parts used & Habit & Preparation methods & Utilisation & RFC \\
\hline $\begin{array}{l}\text { Colophospermum mopane } \\
\text { (J.Kirk ex Benth.) J.Kirk ex } \\
\text { J.Léonard, Fabaceae }\end{array}$ & Leaves & Tree & $\begin{array}{l}\text { Boiled and mixed with salt and } \\
\text { extract given to livestock }\end{array}$ & $\begin{array}{c}\text { Diarrhoea in cattle and } \\
\text { sheep }\end{array}$ & 0.33 \\
\hline $\begin{array}{c}\text { Dodonaea viscosa Jacq var. } \\
\text { angustifolia (L.f) Benth., } \\
\text { Sapindaceae }\end{array}$ & Leaves & Tree & $\begin{array}{c}\text { Pounded and mixed with leaves of } \\
\text { Nicotiana tabacum and applied } \\
\text { topically }\end{array}$ & Wounds in cattle and pigs & 0.33 \\
\hline $\begin{array}{c}\text { Englerophytum } \\
\text { magalismontanum (Sond.) } \\
\text { T.D.Penn., Sapotaceae }\end{array}$ & Leaves & Tree & $\begin{array}{l}\text { Pounded and mixed with drinking } \\
\text { water }\end{array}$ & Prevent abortion in cattle & 0.33 \\
\hline $\begin{array}{c}\text { Grewia flavescens Juss., } \\
\text { Malvaceae }\end{array}$ & Leaves & Tree & Dry or fresh leaves given to sheep & Fodder for sheep & 0.33 \\
\hline $\begin{array}{l}\text { *Jatropha curcas L., } \\
\text { Euphorbiaceae }\end{array}$ & Roots & Tree & $\begin{array}{c}\text { Pounded and mixed with drinking } \\
\text { water }\end{array}$ & Worms in cattle & 0.33 \\
\hline *Melia azedarach L., Meliaceae & Leaves & Tree & Boiled and applied topically & Eye infections in cattle & 0.33 \\
\hline *Morus alba L., Moraceae & Leaves & Tree & $\begin{array}{c}\text { Dry or fresh leaves given to } \\
\text { livestock }\end{array}$ & $\begin{array}{l}\text { Fodder for sheep and } \\
\text { goats }\end{array}$ & 0.33 \\
\hline $\begin{array}{l}\text { *Persea americana Mill., } \\
\text { Lauraceae }\end{array}$ & Roots & Tree & Pounded and applied topically & $\begin{array}{l}\text { Wounds in cattle, } \\
\text { donkeys, sheep, goats } \\
\text { and pigs }\end{array}$ & 0.33 \\
\hline \multirow[t]{2}{*}{ *Piper nigrum L., Piperaceae } & \multirow[t]{2}{*}{ Seeds } & \multirow[t]{2}{*}{ Shrub } & Pounded and applied topically & $\begin{array}{l}\text { Wounds in cattle, } \\
\text { donkeys, sheep, goats } \\
\text { and pigs }\end{array}$ & 0.33 \\
\hline & & & $\begin{array}{c}\text { Pounded and mixed with drinking } \\
\text { water }\end{array}$ & $\begin{array}{l}\text { Worms in cattle, donkeys, } \\
\text { sheep, goats and pigs }\end{array}$ & 0.33 \\
\hline${ }^{\star}$ Psidium guajava L., Myrtaceae & Leaves & Tree & Boiled and extract given to livestock & Diarrhoea in pigs & 0.33 \\
\hline $\begin{array}{l}{ }^{*} \text { Ricinus communis L., } \\
\text { Euphorbiaceae }\end{array}$ & Leaves & Shrub & $\begin{array}{l}\text { Pounded and mixed with petrol }{ }^{\circledR} \text { or } \\
\text { water and mixture sprayed }\end{array}$ & $\begin{array}{c}\text { Flies in chickens and } \\
\text { doves }\end{array}$ & 0.33 \\
\hline $\begin{array}{c}\text { Vachellia nilotica (L.) } \\
\text { P.J.H.Hurter \& Mabb., Fabaceae }\end{array}$ & Leaves & Tree & Boiled and extract given to livestock & Diarrhoea in sheep & 0.33 \\
\hline Waltheria indica L., Malvaceae & Leaves & Shrub & Boiled and extract given to livestock & Diarrhoea in cattle & 0.33 \\
\hline
\end{tabular}

identification was done in the field and authentication of collected specimens was done by Prof Maroyi, a professional taxonomist and plant names were confirmed using 'the plant list' (http://www.theplantlist.org/tpl1.1/record/kew-4776111).

We determined the Relative Frequency of Citation (RFC) of reported plant species using the following formula:

$$
\mathrm{RFC}=\mathrm{FC} / \mathrm{N} ;(0<\mathrm{RFC}<1)
$$

This index shows the local importance of each species and is given by the frequency of citation (FC), that is the number of informants mentioning the use of species divided by the total number of informants participating in the study [29].

\section{RESULTS AND DISCUSSION}

Fifty two species from 32 plant families were used for 18 ethnoveterinary purposes (Table 1 ). The majority of the species $(21.2 \%)$ were used as fodder, followed by ethnoveterinary medicinal applications against wounds (19.2\%), diarrhoea (17.3\%), ticks (13.5\%) and worms $(11.5 \%)$. This diversity of plants in the current study is much higher than that recorded amongst other South African cultures such as Vhavenda [17,30], VaTsonga [13] and Xhosa [16], probably because these previous studies focused explicitly on plants used as ethnoveterinary medicines. Nevertheless, the relatively high variety of plant species recorded in the present study point out the broad extent of participants' knowledge of ethnoveterinary plants, and also demonstrates that plant species are a fundamental resource for enhancing livestock development in the Limpopo province. Trees (57.6\%), shrubs (28.8\%) and herbs $(13.4 \%)$ were the most widely used growth forms (Table 1). The plant parts used as fodder and ethnoveterinary medicines were the bark, bulbs, fruits, leaves, roots, seeds and whole plant. The leaves were the most frequently used $(59.6 \%)$, followed by roots $(28.8 \%)$ (Figure 2). The variation in the preferences of 
plant habits for the documented uses by the Bapedi households could be attributed to the wide agroecological diversity and specific indigenous knowledge associated with the documented species. However, the high use of trees and shrub in this study may be due to the fact that these growth forms are mainly available throughout the year and thus, can provide plant material needed as fodder as well as ethnoveterinary medicines whenever these resources are required.

Table 2: Ethnoveterinary Uses of Plants in Ga-Mphahlele Area, the Limpopo Province, South Africa

\begin{tabular}{|c|c|c|}
\hline Use & No. of species & $\%$ \\
\hline Fodder & 11 & 21.2 \\
\hline Wounds & 10 & 19.2 \\
\hline Diarrhoea & 9 & 17.3 \\
\hline Ticks & 7 & 13.5 \\
\hline Worms & 6 & 11.5 \\
\hline Constipation & 4 & 7.7 \\
\hline Dermatophilosis & 2 & 3.8 \\
\hline Eye infections & 2 & 3.8 \\
\hline Flies & 2 & 3.8 \\
\hline Aggression & 1 & 1.9 \\
\hline Cold and cough & 1 & 1.9 \\
\hline Enhance appetite & 1 & 1.9 \\
\hline Facilitation of birth & 1 & 1.9 \\
\hline Fertility & 1 & 1.9 \\
\hline Heart-water & 1 & 1.9 \\
\hline Internal parasites & 1 & 1.9 \\
\hline Newcastle & 1 & 1.9 \\
\hline Prevent abortion & 1 & 1.9 \\
\hline
\end{tabular}

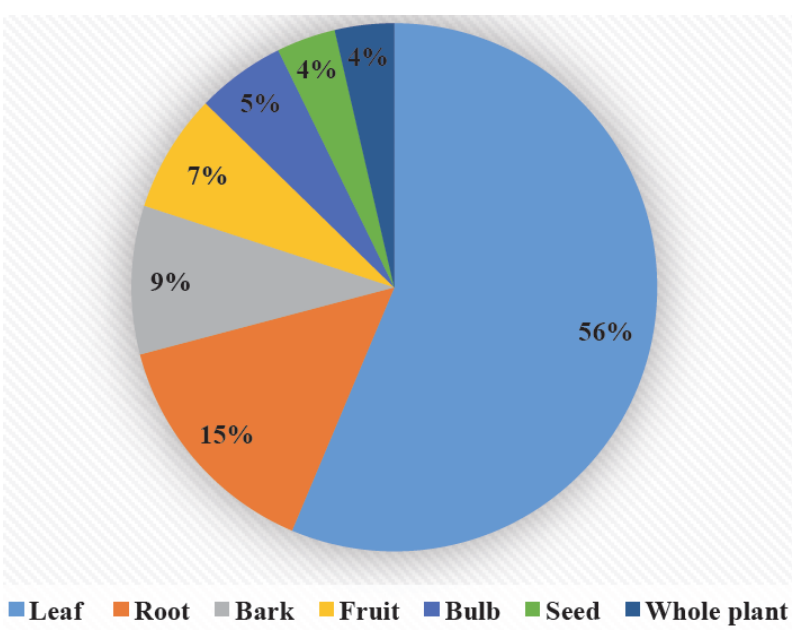

Figure 2: Plant parts used for ethnoveterinary purposes by Bapedi people.
About a third $(32.7 \%)$ of the documented species are exotic to South Africa, among these were: Agave americana L., Aloe vera (L.) Burm, Allium cepa L., Allium sativum L., Carica papaya L., Citrus limon (L.) Burm., Jatropha curcas L., Lantana camara L., Melia azedarach L., Morus alba L., Nicotiana tabacum L., Persea americana Mill., Piper nigrum L., Psidium guajava L., Ricinus communis L., Urtica urens L. and Zea mays L. (Table 1). These findings corroborate previous research which showed that exotic plants cultivated worldwide as ornamentals or food plants are often incorporated into traditional pharmacopoeias as herbal medicines mainly due to their use-versatility applications [31]. A large number of the documented species $(59.6 \%)$ were from 11 families (Table 3 ) as the other 19 families were represented by one species each (Table 1). Plant families with the highest number of species were: Fabaceae (8 species), Asphodelaceae (4 species), Malvaceae (3 species), Amaryllidaceae, Apocynaceae, Euphorbiaceae, Moraceae, Poaceae, Rutaceae, Solanaceae and Verbenaceae with two species (Table 3). The species with frequency of citation (RFC) higher than 0.5 included (in their order of importance): Citrullus lanatus (Thunb.) Matsum. \& Nakai (fodder), Vachellia karroo (Hayne) Banfi \& Glasso (ethnoveterinary medicine and fodder), Sclerocarya birrea (A.Rich.) Hochst. subsp. caffra (Sond.) Kokwaro (fodder), Aloe ferox Mill. (ethnoveterinary medicine), Drimia sanguinea (Schinz) Jessop (ethnoveterinary medicine), Sarcostemma viminale (L.) R.Br. subsp. viminale (ethnoveterinary medicine), Sorghum bicolor (L.) Moench (fodder), Ficus thonningii Blume (ethnoveterinary medicine and fodder), Dichrostachys cinerea (L.) Wight \& Arn.

Table 3: Families with the Largest Number of Plants Used for Veterinary Purposes in Ga-Mphahlele Area, the Limpopo Province

\begin{tabular}{|c|c|c|}
\hline Family & No. of species & $\%$ \\
\hline \hline Fabaceae & 8 & 15.4 \\
\hline Asphodelaceae & 4 & 7.7 \\
\hline Malvaceae & 3 & 5.8 \\
\hline Amaryllidaceae & 2 & 3.8 \\
\hline Apocynaceae & 2 & 3.8 \\
\hline Euphorbiaceae & 2 & 3.8 \\
\hline Moraceae & 2 & 3.8 \\
\hline Poaceae & 2 & 3.8 \\
\hline Rutaceae & 2 & 3.8 \\
\hline Solanaceae & 2 & 3.8 \\
\hline Verbenaceae & 2 & 3.8 \\
\hline
\end{tabular}


(ethnoveterinary medicine and fodder), Lippia javanica (Burm.f.) Spreng (ethnoveterinary medicine), Zea mays L. (fodder), Adansonia digitata L. (fodder), Nicotiana tabacum L. (ethnoveterinary medicine), Tribulus terrestris L. (ethnoveterinary medicine) and Aloe marlothii A.Berger (ethnoveterinary medicine) (Table 1).

More than three quarters $(76.9 \%)$ of the documented plant species were used on cattle, followed by goats $(71.2 \%)$, sheep $(69.2 \%)$, donkeys (38.5\%), pigs $(28.8 \%)$, chickens $(21.2 \%)$ and dog $(1.9 \%)$ (Table 4). When we asked participants about the importance of plants in ethnoveterinary practices, the participants highlighted factors such as fodder quality, the ability of plant species to fatten livestock, increase milk production, treat livestock and poultry diseases. Our findings corroborate results obtained by Yirga et al. [4] which showed that ethnoveterinary medicine play an important role in animal production and livelihood development as they provide valuable alternatives to and complement Western veterinary medicines which are accessible, easy to prepare and administer at very little or no cost to the farmers.

Table 4: Dog, Livestock and Poultry Species Treated with Ethnoveterinary Medicines in Ga-Mphahlele Area, the Limpopo Province

\begin{tabular}{|c|c|c|}
\hline Animal species & No. of plant species & $\%$ \\
\hline \hline Cattle & 40 & 76.9 \\
\hline Goats & 37 & 71.2 \\
\hline Sheep & 36 & 69.2 \\
\hline Donkeys & 20 & 38.5 \\
\hline Pigs & 15 & 28.8 \\
\hline Chicken & 11 & 21.2 \\
\hline Dog & 1 & 1.9 \\
\hline
\end{tabular}

\section{CONCLUSION}

This paper provided detailed information on plant species used for veterinary purposes in Ga-Mphahlele area in the Limpopo province, South Africa. Results of this research revealed that local people have extensive knowledge on fodder species and plant species used as ethnoveterinary medicines. Knowledge on which forage and ethnoveterinary medicinal plants are suitable for various livestock and poultry species enables local communities to better plan and manage their livestock and poultry species in a sustainable manner. The traditional knowledge about plant resources in relation to forage and ethnoveterinary medicinal plants in the Ga-Mphahlele region in the Limpopo province enable researchers, agricultural extension officers and policy makers to appreciate how the Bapedi people in the province perceive and utilize plant resources around them. The efficacy of ethnoveterinary medicines identified in this study need to be fully investigated in terms of their phytochemistry and pharmacological activities. Lack of scientific validation corroborating the ethnoveterinary medicinal applications of several plant species is the major reason for non-adoption of ethnoveterinary medicines throughout the world.

\section{ACKNOWLEDGEMENTS}

The authors are grateful to the traditional healers practising in the Lepelle-Nkumpi Municipality for participating in this study and sharing their valuable knowledge on medicinal plants used against oral diseases. This study was possible through a grant provided by National Research Foundation (NRF) and Govan Mbeki Research and Development Centre (GMRDC), University of Fort Hare with grant number T398 and C169, respectively.

\section{REFERENCES}

[1] Tabuti RJS, Lye AK. Fodder plants for cattle in Kaliro District, Uganda. Afr Stud Monogr 2009; 30: 161-170.

[2] Minja MMT. Medicinal plants used in the promotion of animal health in Tanzania. Rev Sci Tech Off Int Epiz 1994; 13: 905925.

https://doi.org/10.20506/rst.13.3.800

[3] Kioko J, Baker J, et al. Ethnoecological knowledge of ticks and treatment of tick-borne diseases among Maasai people in Northern Tanzania. Vet World 2015; 8: 755-762. https://doi.org/10.14202/vetworld.2015.755-762

[4] Yirga G, Teferi $M$, et al. An ethnoveterinary survey of medicinal plants used to treat livestock diseases in SehartiSamre district, Northern Ethiopia. Afr J Plant Sci 2012; 6: 113-119.

[5] Maroyi A. Use of traditional veterinary medicine in Nhema communal area of the Midlands Province, Zimbabwe. Afr $\mathrm{J}$ Tradit Complement Altern Med 2012; 9: 315-322. https://doi.org/10.4314/ajtcam.v9i3.3

[6] Birhann T, Abera D. Survey of ethno-veterinary medicinal plants at selected homes in Guduru district, Western Ethiopia. Afr J Plant Sci 2015; 9: 185-192. https://doi.org/10.5897/AJPS2014.1229

[7] Kone WM, Atindehou KK. Ethnobotanical inventory of medicinal plants used in traditional veterinary medicine in Northern Cote d'I Voire (West Africa). S Afr J Bot 2008; 74: 76-84.

https://doi.org/10.1016/j.sajb.2007.08.015

[8] Gabalebatse $\mathrm{M}$, Ngwenya $\mathrm{BN}$, et al. Ethno-veterinary practices amongst livestock farmers in Ngamiland district, Botswana. Afr J Trad Compl Alt Med 2013; 10(3): 490-502. https://doi.org/10.4314/ajtcam.v10i3.16

[9] Phondani PC, Maikhuri PK, Kala CP. Ethnoveterinary uses of medicinal plants among traditional herbal healers in Alaknanda catchment of Uttarakhand, India. Afr J Trad Compl Alt Med 2010; 7(3): 195-206.

https://doi.org/10.4314/ajtcam.v7i3.54775 
[10] Suroowan S, Javeed $\mathrm{F}$, et al. Ethnoveterinary health management practices using medicinal plants in South Asia: a review. Vet Res Commun 2017; 41: 147-168. https://doi.org/10.1007/s11259-017-9683-z

[11] Aziz MA, Khan AH, et al. Traditional uses of medicinal plants used by Indigenous communities for veterinary practices at Bajaur Agency, Pakistan. J Ethnobiol Ethnomed 2018; 14: 11. https://doi.org/10.1186/s13002-018-0212-0

[12] Patil NB. A report on medicinal plants used in ethno veterinary practices of village peoples in satpuda hills in shirpur taluka (Dist-Dhule, Maharashtra). Pharma Tutor; 2019; 7(1): 38-41.

[13] Luseba D, Van der Merwe D, Ethnoveterinary medicine practices among Tsonga speaking people of South Africa. Onderstepoort J Vet Res 2006; 73: 115-122. https://doi.org/10.4102/ojvr.v73i2.156

[14] Dold AP, Cocks ML. Traditional veterinary medicine in the Alice district of the Eastern Cape Province, South Africa. S Afr J Sci 2001; 97: 375-379.

[15] Maphosa V, Masika PJ. Ethnoveterinary uses of medicinal plants: A survey of plants used in the ethnoveterinary control of gastro-intestinal parasites of goats in the Eastern Cape Province, South Africa. Pharm Biol 2010; 48: 697-702. https://doi.org/10.3109/13880200903260879

[16] Sanhokwe M, Mupangwa J, et al. Medicinal plants used to control internal and external parasites in goats. Onderstepoort J Vet Res 2016; 83: 1-7. https://doi.org/10.4102/ojvr.v83i1.1016

[17] Luseba D, Tshisikhawe MP. Medicinal plants used in the treatment of livestock diseases in Vhembe region, Limpopo province, South Africa. J Med Plants Res 2012; 7: 593-601.

[18] Magwede K, Tshisikhawe MP, et al. Ethnobotanical survey of medicinal plants used in treatment of ticks. Int $\mathrm{J}$ Expe Biol 2014; 83: 155-165.

[19] Kunene K, Wilson RAC, Myeni NP. The use of trees, shrubs and herbs in livestock production by communal farmers in northern KwaZulu-Natal, South Africa. Afr J Range For Sci 2009; 12: 271-274.

[20] Lodge T. Provincial government and state authority in South Africa. J Southern Afr Stud 2005; 31: 748-749. https://doi.org/10.1080/03057070500370480
[21] Alhaji NB, Babalobi OO. Participatory epidemiology of ethnoveterinary practices Fulani pastoralists used to manage contagious bovine pleuropneumonia and other cattle ailments in Niger State, Nigeria. J Vet Med 2015; vol 2015, art ID 460408.

[22] Statistic South Africa, Community profile databases, and geographical areas: Census 2011. Statistic South Africa, Pretoria, 2011.

[23] South African Weather Service (SAWS), South African rainfall data. http://www.weathersa.co.za. (site accessed 10/08/2018), 2012.

[24] Limpopo State of the Environment Report: State of the Environment Reports. Pretoria: Department of Environmental Affairs; 2005. http://www.environment.gov.za/soer/reports/ limpopo.html, accessed on 15 April 2019.

[25] Mucina L, Rutherford MC: The Vegetation of South Africa, Lesotho and Swaziland. Strelizia 19. Pretoria: South African National Biodiversity Institute; 2006.

[26] Crouch $M$, McKenzie $H$. The logic of small samples in interview-based qualitative research. Soc Sci Inf 2006; 45(4): 483-499. https://doi.org/10.1177/0539018406069584

[27] Guest G, Bunce A, Johnson L. How many interviews are enough? an experiment with data saturation and variability. Field Meth 2006; 18(1): 59-82.

https://doi.org/10.1177/1525822X05279903

[28] Latham JR. A framework for leading the transformation to performance excellence part I: CEO perspectives on forces, facilitators, and strategic leadership systems. Quality Manag J 2013; 20(2): 12-33. https://doi.org/10.1080/10686967.2013.11918095

[29] Ahmad M, Sultana S, et al. An ethnobotanical study of medicinal plants in high mountainous region of Chail valley (District Swat-Pakistan). J Ethnobiol Ethnomed 2014; 10: 36. https://doi.org/10.1186/1746-4269-10-36

[30] Mphephu TS. Sustainable natural resource utilisation: A case study of ethnobotanically important plant taxa in the Thulamela Local Municipality, Limpopo Province. (M.Sc. dissertation, University of Johannesburg, Johannesburg), 2017.

[31] Maroyi A. Ethnomedicinal uses of exotic plant species in south-central Zimbabwe. Indian J Trad Knowl 2018; 17(1): 71-77. 